\title{
Corrosion Behavior of AA7075-T73 Aluminum Alloy During Machining of Aeronautical Components
}

\author{
Júlio Cesar Lourenço ${ }^{a}{ }^{\circledR}$, Alain Laurent Marie Robin ${ }^{a}$, Maria Ismenia Sodero Toledo Faria ${ }^{a}$, \\ Luciana Prates Prisco ${ }^{b}$, Mario Coelho Puccini ${ }^{b}$, Lucemar Diogo de Oliveira ${ }^{b}$ \\ ${ }^{a}$ Escola de Engenharia de Lorena, Departamento de Engenharia de Materiais, Lorena, SP, Brasil \\ ${ }^{b}$ Liebherr-Aerospace Brasil, Guaratinguetá, SP, Brasil
}

Received: March 23, 2018; Revised: February 06, 2019; Accepted: May 21, 2019

\begin{abstract}
Corrosion of AA7075-T73 aluminum alloy during machining process was studied. An experimental device was proposed in order to simulate machining procedure. A design of experiments - DOE was used in order to evaluate what process parameter is significant. Some electrochemical tests based on open-circuit potential vs time measurements and potentiodynamic polarization were performed in machining fluid of low and high chloride concentrations. Results from DOE showed that the chloride concentration in machining fluid and the presence or not of a zinc coating on the bench vice jaw material in the machining system, along with the interaction between these both factors are significant. OCP results showed oxide growth with time in low and high chloride concentration machining fluid. Passivity breakdown was only observed in high chloride concentration machining fluid. Best fitted parameters were applied to a large scale aeronautical manufacturing company, achieving $95 \%$ reduction in corrosion appearance on the manufactured parts.
\end{abstract}

Keywords: AA7075, Aircraft industry, Corrosion, Electrochemical tests, Design of experiments.

\section{Introduction}

AA7075 aluminum alloy is a high strength precipitationhardenable alloy used to manufacture aircraft parts such as wings structures and hydraulics components due to its high strength-to-density ratio ${ }^{1-4}$. The higher mechanical resistance of this alloy is achieved by alloying with elements such as $\mathrm{Cu}, \mathrm{Zn}, \mathrm{Cr}, \mathrm{Mg},{ }^{1-2,5-7}$. Intermetallic phases containing $\mathrm{Fe}$ and $\mathrm{Si}$, such as $\mathrm{Al}_{7} \mathrm{Cu}_{2} \mathrm{Fe}, \mathrm{Al}_{23} \mathrm{CuFe}_{4}$ and $\mathrm{Mg}_{2} \mathrm{Si}$ are commonly found in this alloy as inclusions and may have a deleterious effect on fatigue resistance ${ }^{8-9}$. Although the addition of elements improves mechanical properties, the AA7075 alloy has lower corrosion resistance due to corrosion potential difference between second phase and matrix. For example, intermetallic compounds containing $\mathrm{Zn}$ and $\mathrm{Mg}$ are anodic compared to the surrounding aluminum matrix ${ }^{7,10}$, while intermetallic particles containing $\mathrm{Fe}, \mathrm{Cu}$ and $\mathrm{Mn}$ have a cathodic behavior, which leads to severe micro galvaniccoupling corrosion, making AA7XXX alloys usually prone to galvanic corrosion, pitting corrosion, stress corrosion cracking - SCC, crevice corrosion, exfoliation corrosion, dealloying and intergranular cracking. The potential difference between intermetallic phases is the main driving force for localized corrosion and copper-containing compounds such as $\mathrm{Al}_{7} \mathrm{Cu}_{2} \mathrm{Fe}$ have dissolution potential hundred millivolts more positive than aluminum base metal ${ }^{11-13}$.

AA7XXX alloy production process consists in solubilizing alloying elements, followed by quenching and age hardening treatments. Several heat treatments were developed and

*email: julio.lourenco@usp.br for aeronautical applications, T6 and T7 heat treatments are generally applied. The T6 heat treatment leads to the highest mechanical properties, while $\mathrm{T} 7$ is an overaging heat treatment process that promotes $\eta^{\prime}$ metastable and $\eta$ equilibrium phases precipitation, and increases the precipitation coarsening at grain boundaries. This coarsening explains the higher resistance to SCC and exfoliation corrosion in type T73 temper ${ }^{11,12,14-17}$.

The manufacture of AA7075-T73 parts for aeronautical applications is composed of the following steps ${ }^{1-2}$ :

Machining $\rightarrow$ deburring $\rightarrow$ penetrant liquid inspection $\rightarrow$ anodizing $\rightarrow$ sealing $\rightarrow$ extra parts assembly (to protect fragile parts) $\rightarrow$ final inspection

Although the $\mathrm{T} 73$ heat treatment employs a second aging process for corrosion resistance improvement, the alloy may undergo corrosion during machining step where surface material is constantly removed in contact with machining fluid and has direct contact with other machining equipment parts, such as the bench vice jaw. Machining fluid is a complex mixture of petroleum compounds, commercial bactericidal oil, commercial cutting fluid, and other solutions. The $\mathrm{pH}$ of the machining fluid is slightly basic in order to protect the machining equipment, but aluminum tends to form complex oxides at high $\mathrm{pH}$ levels ${ }^{3,16}$. Several process parameters must be taken into account and controlled during machining AA7075 alloy for aeronautical components, such as the use of protective oil before and after machining, chloride concentration in the machining fluid, Fe contamination from previous steel machining that remains in the machining fluid. 
The purpose of the study was to investigate what parameters in the machining step were significant for the appearance of corrosion on AA7075-T73 alloy. An experimental device was developed to simulate the machining process. A design of experiments (DOE) was employed to analyze and evaluate the parameters to be controlled in machining aircraft parts.

Some electrochemical experiments based on open-circuit potential measurements and potentiodynamic polarization were carried out in machining fluid with low and high chloride concentrations.

\section{Experimental Procedure}

AA7075-T73 aeronautical parts were supplied by a multinational manufacturer company due to out-of-specification final dimensions after machining step. These parts were cut longitudinally and it was assured that all samples had the same superficial area. Figure 1 shows two samples.

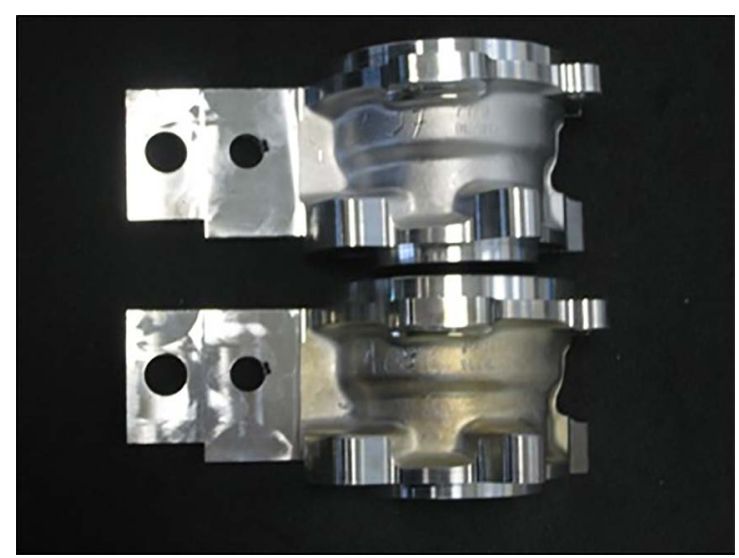

Figure 1. AA7075-T73 parts used in the study

Corrosion of the aluminum alloy appeared right after the machining process was finished. Figure 2 shows, as an example, a machined part that presented corroded areas.
The machining process was simulated by an experimental device consisting in a hydraulic system composed of two reservoirs and one hydraulic pump, which constantly sprayed machining fluid through a pistol grip hose onto the samples with the same pressure as in the machining equipment. Figure 3 shows a schematic drawing of the device used to perform the experiments. The two reservoirs had a small difference in height, so that the machining liquid did not become stagnant in one reservoir, assuring the constant composition of the fluid.

Commercial machining fluid with a sulfate/phosphate free bactericidal oil was used. These ions are known to cause oxidation of aluminum at basic $\mathrm{pH}$ levels.

Most variables to be studied were directly related to the machining process and some parameters were associated to some procedure right after machining: chloride concentration in the machining fluid, superficial state (Zn-coated or not coated) of the bench vice jaw in the machining equipment (part that holds the aluminum part at the CNC lathe and has direct contact with the sample part), AA7075-T73 machined part storage condition after machining step for oil protection (wet with the machining fluid or cleaned and dried in oven), iron contamination concentration in the machining fluid and waiting time to receive the oil protection after machining process. Corrosion analysis was performed after the waiting time.related to each experiment. The values of these factors can vary in specific ranges during machining process according to aeronautical standards. A low level and a high level for each variable were defined according to industry know-how. A $2^{n-p}$ fractional factorial DOE was created using Minitab software. Table 1 shows the controlling factors and their respective low and high levels.

Figure 4 shows the experimental device simulating the machining process. Other factors as spraying pressure of fluid, $\mathrm{pH}$ (7.5-8.0), water hardness (higher than $4 \mathrm{dH}$ ) and spraying time ( 6 hours) were controlled in order to not influence the experimental results. For B parameter -
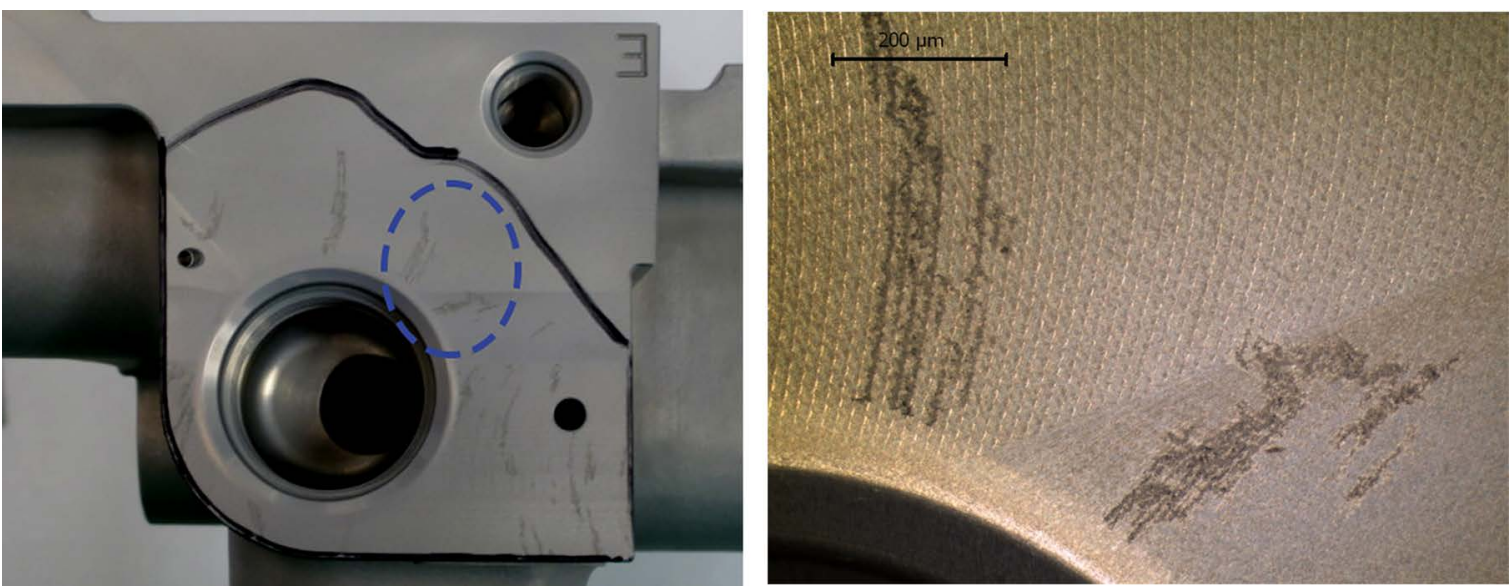

Figure 2. AA7075-T73 machined part presenting corroded areas right after the machining step 


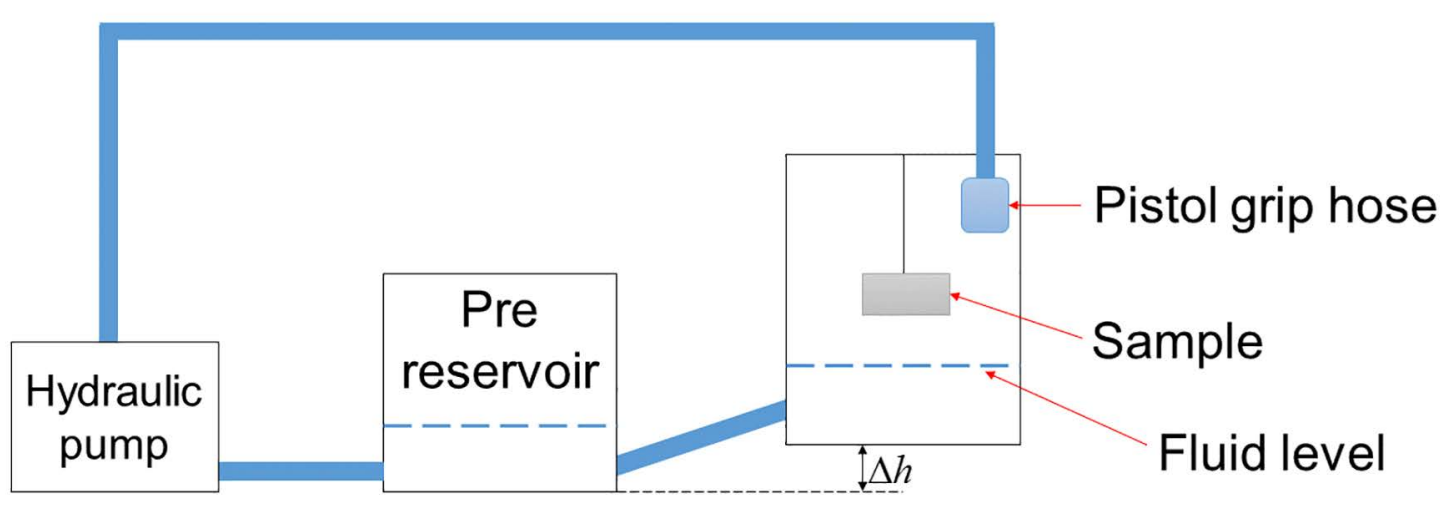

Figure 3. Schematic drawing of the device developed to simulate machining process

Table 1. Controlling factors and their low and high levels for machining step

\begin{tabular}{clcc}
\hline Factor & $\begin{array}{l}\text { Controlling } \\
\text { parameter }\end{array}$ & Low level & High level \\
\hline A & $\begin{array}{l}\text { Chloride } \\
\text { concentration } \\
\text { (ppm) }\end{array}$ & 100 & 400 \\
B & $\begin{array}{l}\text { Device State } \\
\text { (Machining bench } \\
\text { vice jaw) }\end{array}$ & Zinc-coated & Not coated \\
C & $\begin{array}{l}\text { Part condition for } \\
\text { oil protection }\end{array}$ & Dry & Wet \\
D & $\begin{array}{l}\text { Fe contamination } \\
\text { in machining fluid } \\
\text { (ppm) }\end{array}$ & 0 & 300 \\
E & $\begin{array}{l}\text { Waiting time } \\
\text { to receive oil } \\
\text { protection (days) }\end{array}$ & 7 & 21 \\
\hline
\end{tabular}

Device state, it was used a $2 \mathrm{~cm}$ x $3 \mathrm{~cm}$ block of the same material used for the bench vice jaw in industrial machining equipment, i.e. cast iron (high level in Table 1). The lowlevel condition corresponds to the block coated with zinc layer (Table 1). The block was tightly attached to the sample during the experiments.

After each experiment, images of the sample surface were obtained by optical microscopy and the corroded areas were quantified by image analysis software - ImageJ (open source image analysis software). It was set the same scale for all images. Figure 5 shows three corroded regions on one image and the respective and total corroded areas. The total corroded area for each sample was used as response variable for the DOE.

To provide more information on corrosion of AA7075-T73 alloy during machining, conventional electrochemical tests were also performed. The tests were carried out in the machining fluid using low (100 ppm) and high (400 ppm) chloride concentrations. The solutions were naturally aerated and without stirring. A typical three-electrode cell

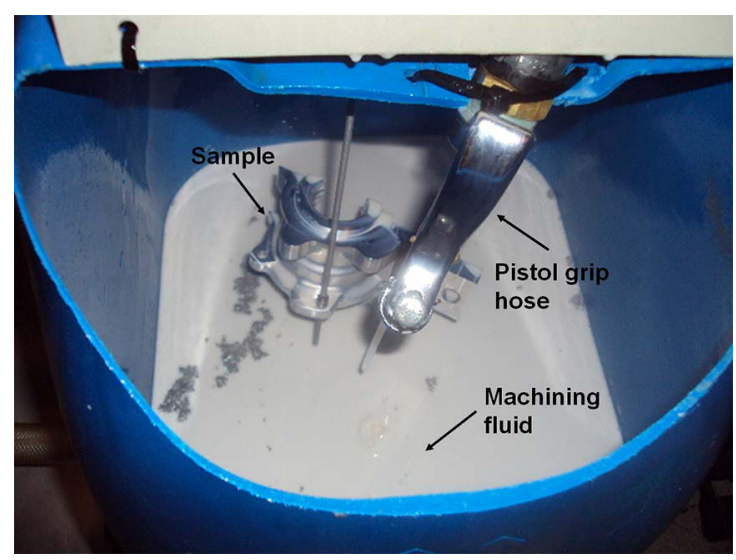

Figure 4. Experimental device simulating machining process

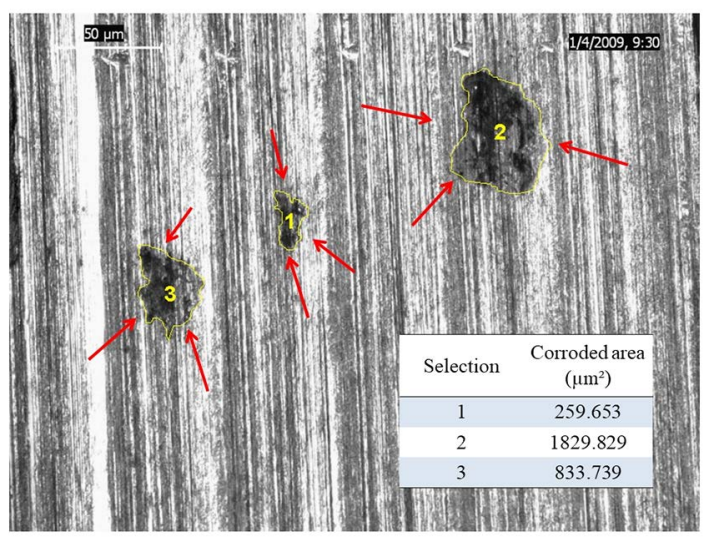

Figure 5. Optical image of corroded regions in AA7075-T73 alloy during simulated machining process and the respective quantification of corroded areas

was used with a square-shaped $18 \mathrm{~cm}^{2}$ platinum sheet as counter-electrode and a saturated calomel electrode (SCE) as reference electrode. The electrochemical tests were performed in the following sequence: open-circuit potential measurement during 1.5 hours, and potentiodynamic cathodic and anodic polarization using potential scan rate of $1 \mathrm{mV} \cdot \mathrm{s}^{-1}$. The Electrochemical Interface SOLARTRON model 1287A 
controlled by the Ecorr/Zplot SOLARTRON model 125587S software was used.

\section{Results}

\subsection{DOE results for machining step}

Table 2 shows the combination of process parameters for the 16 experiments performed according DOE. The last column presents the values of the response variable (total corroded area).

Figure 6 shows the Pareto chart of the effects of the controlling variables on the response variable. Results from the DOE analysis show that presence or not of $\mathrm{Zn}$ coating on bench vice jaw coating - factor $\mathrm{B}$, and chloride concentration in the machining fluid - factor $\mathrm{A}$ are the main factors that contribute to the corrosion appearance on AA7075-T73 parts. The interaction BA is also significant, showing that the bench vice jaw superficial state and chloride concentration have together an extra contribution to the final corrosion amount. On the other hand, factors $\mathrm{C}$ (part condition for oiling), D (iron contamination in the machining fluid) and
E (waiting time for part to receive protective oil) that were expected to be crucial factors for corrosion control did not present significance for corrosion appearance.

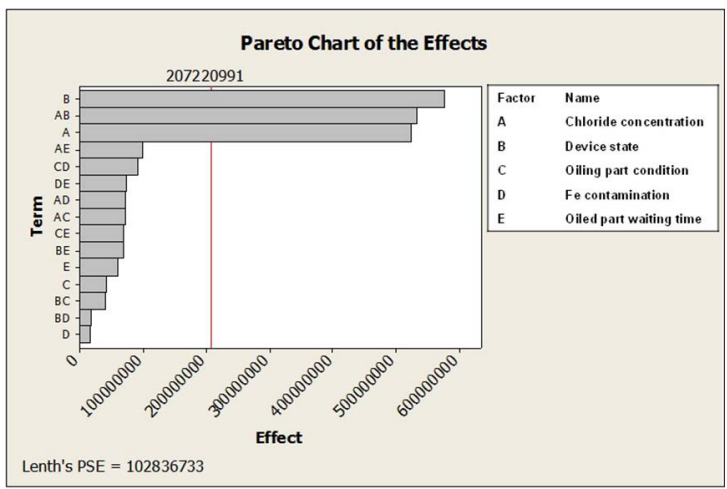

Figure 6. Pareto chart of the effects for the factors and their first order interactions on the ocurrence of corrosion on AA7075-T73 alloy parts

Table 2. $2^{5-1}$ fractional factorial design for control factors and their respective levels (according to Table 1 ) and response variable (total corroded area)

\begin{tabular}{|c|c|c|c|c|c|c|c|c|c|}
\hline StdOrder & RunOrder & CenterPt & Blocks & $\begin{array}{c}\text { Cloride } \\
\text { concentration } \\
(\mathrm{ppm})\end{array}$ & $\begin{array}{l}\text { Superficial } \\
\text { device } \\
\text { state }\end{array}$ & $\begin{array}{l}\text { Part } \\
\text { condition } \\
\text { for oil } \\
\text { protection }\end{array}$ & $\begin{array}{c}\mathrm{Fe} \\
\text { contamination } \\
(\mathrm{ppm})\end{array}$ & $\begin{array}{l}\text { Waiting } \\
\text { time to } \\
\text { receive } \\
\text { protective } \\
\text { oil (days) }\end{array}$ & $\begin{array}{c}\text { Total } \\
\text { corrosion } \\
\text { area }\left(\mu \mathrm{m}^{2}\right)\end{array}$ \\
\hline 3 & 1 & 1 & 1 & 100 & Not-coated & Dry & 0 & 7 & 0 \\
\hline 8 & 2 & 1 & 1 & 400 & Not-coated & Wet & 0 & 7 & 1467472056 \\
\hline 4 & 3 & 1 & 1 & 400 & Not-coated & Dry & 0 & 21 & 924514448 \\
\hline 2 & 4 & 1 & 1 & 400 & $\begin{array}{l}\text { Zinc- } \\
\text { coated }\end{array}$ & Dry & 0 & 7 & 0 \\
\hline 11 & 5 & 1 & 1 & 100 & Not-coated & Dry & 300 & 21 & 168037514 \\
\hline 15 & 6 & 1 & 1 & 100 & Not-coated & Wet & 300 & 7 & 44869335 \\
\hline 6 & 7 & 1 & 1 & 400 & $\begin{array}{l}\text { Zinc- } \\
\text { coated }\end{array}$ & Wet & 0 & 21 & 0 \\
\hline 7 & 8 & 1 & 1 & 100 & Not-coated & Wet & 0 & 21 & 0 \\
\hline 1 & 9 & 1 & 1 & 100 & $\begin{array}{c}\text { Zinc- } \\
\text { coated }\end{array}$ & Dry & 0 & 21 & 12614293 \\
\hline 12 & 10 & 1 & 1 & 400 & Not-coated & Dry & 300 & 7 & 1070581129 \\
\hline 5 & 11 & 1 & 1 & 100 & $\begin{array}{l}\text { Zinc- } \\
\text { coated }\end{array}$ & Wet & 0 & 7 & 0 \\
\hline 14 & 12 & 1 & 1 & 400 & $\begin{array}{l}\text { Zinc- } \\
\text { coated }\end{array}$ & Wet & 300 & 7 & 0 \\
\hline 13 & 13 & 1 & 1 & 100 & $\begin{array}{l}\text { Zinc- } \\
\text { coated }\end{array}$ & Wet & 300 & 21 & 21567663 \\
\hline 9 & 14 & 1 & 1 & 100 & $\begin{array}{l}\text { Zinc- } \\
\text { coated }\end{array}$ & Dry & 300 & 7 & 0 \\
\hline 16 & 15 & 1 & 1 & 400 & Not-coated & Wet & 300 & 21 & 976493109 \\
\hline 10 & 16 & 1 & 1 & 400 & $\begin{array}{l}\text { Zinc- } \\
\text { coated }\end{array}$ & Dry & 300 & 21 & 0 \\
\hline
\end{tabular}


Figure 7 shows the BA interaction plot. In statistics, an interaction may arise when considering the relationship among control variables, and describes a situation in which the simultaneous influence of two variables on a third is not additive. In this case, this relationship depends on the values of the interacting variables. From Figure 7, the worst condition during machining process is not-coated bench vice jaw device and the machining fluid with a high chloride concentration, leading to the highest corroded area. With low chloride concentration in the machining fluid, the state of the bench vice jaw had almost no influence, showing low superficial corrosion. When zinc-coated device is used, it corrodes preferentially to the AA7075-T73 part, since zinc is anodic when compared to aluminum in the galvanic series; then no corrosion of the part is observed. When the bench vice is not coated, the material, cast iron, is in contact with the AA7075-T73 part. Then, the bench vice jaw is now cathodic and the aluminum part is anodic in the galvanic couple. In low concentrated chloride fluid, the galvanic current certainly was low and almost no corrosion of the aluminum part occurred. On the contrary, at high concentrations of chlorides, the galvanic current was high and severe corrosion was observed.

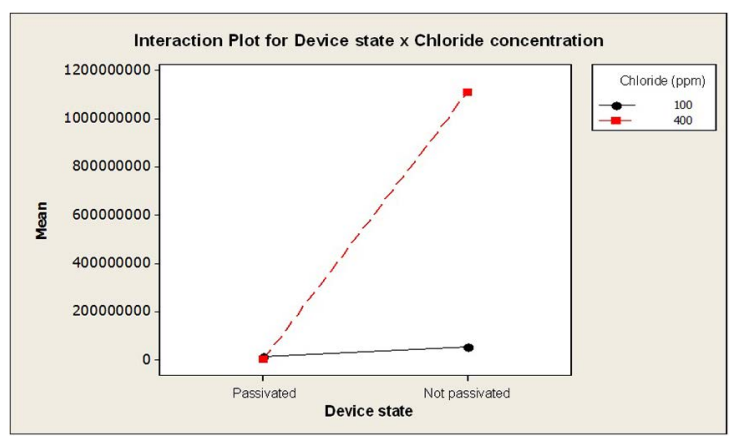

Figure 7. Interaction plot for BA, device state $\mathrm{x}$ chloride concentration

Some works and reports are available on corrosiveness of cutting, machining and drawing fluids ${ }^{18-21}$.

Kostadin et al. ${ }^{18}$ studied the effect of cutting fluids on the corrosion behavior of martensitic stainless steels using gravimetric and electrochemical techniques. They also used statistical methods based on L18 Taguchi orthogonal array and the smaller-the- better criterion. They showed the nonsignificant influence of cooling method on the corrosion resistance of the machined surface.

Ramakrishnan et al. ${ }^{19}$ also investigated the corrosion of copper in drawing fluids using the same methodology. They observed that the characteristics of water for mixing $(\mathrm{pH}$, conductivity) are very important and that the presence of salts, such as chloride, can cause the corrosion of tools and copper machined parts. This latter fact is in accordance with our results on the significant effect of chloride concentration in machining fluid.
Trim technical bulletin ${ }^{20}$ also reported that chloride ions present in softened water is particularly aggressive in corrosion processes. It is also stated that the pair of two dissimilar metals can lead to galvanic current and to the corrosion of the less noble part. This is congruent with our results as it was shown that a zinc-coated bench vice jaw leads to lower corrosion of the aluminum alloy machined parts than an uncoated device (cast iron).

\subsection{Electrochemical results}

Figure 8 shows the variation of the open-circuit potential of AA7075-T73 alloy with time in low and high chloride concentrations machining fluid. In both conditions, the curves had a tendency to shift to more positive potential values, indicating passive behavior and growth of oxide layer.

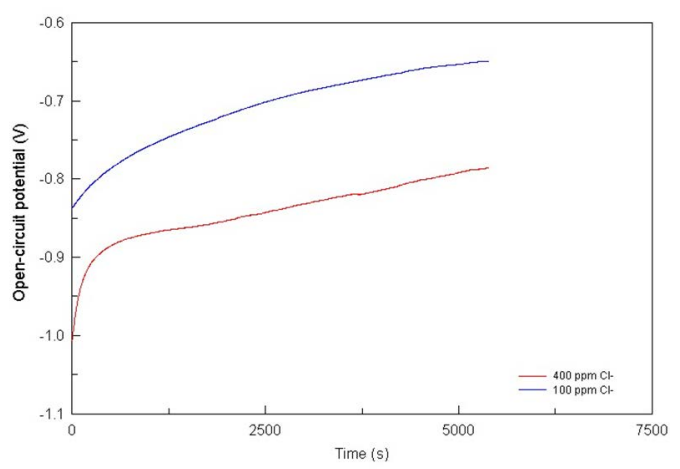

Figure 8. OCP versus time for AA7075-T73 in machining fluid with low and high chloride concentrations

The final potentials after $1.5 \mathrm{~h}$ immersion, which are known as corrosion potentials Ecorr, are $-0.649 \mathrm{~V} / \mathrm{SCE}$ and $-0.785 \mathrm{~V} / \mathrm{SCE}$ in low and high chloride concentration fluid, respectively. The less noble Ecorr value in high concentration chloride solution indicates the aggressive character of the chloride ions.

Figure 9 shows the potentiodynamic polarization curves of AA7075-T73 alloy in low1.2 x 10 $0^{-7} \mathrm{~A}_{\mathrm{cm}} \mathrm{cm}^{-2}$ and high chloride concentration machining fluid. The corresponding corrosion current density values obtained by the usual Tafel extrapolation method using Cview automatic Tafel fitting tool were $1.2 \times 10^{-7} \mathrm{~A} . \mathrm{cm}^{-2}$ and $5.5 \times 10^{-7} \mathrm{~A} . \mathrm{cm}^{-2}$, respectively. This proves that machining fluid containing low chloride concentration is less aggressive. This result is consistent with DOE analysis that showed that low chloride concentration is the better condition for using machining fluid.

The anodic polarization curve obtained in low chloride concentration fluid shows stability of the oxide film up to $1 \mathrm{~V} / \mathrm{SCE}$. On the contrary, breakdown of the oxide film is observed at $+0.696 \mathrm{~V} / \mathrm{SCE}$ in high chloride concentration fluid (Figure 9). Some oscillations of current before breakdown are attributed to pitting/repassivation phenomena. 


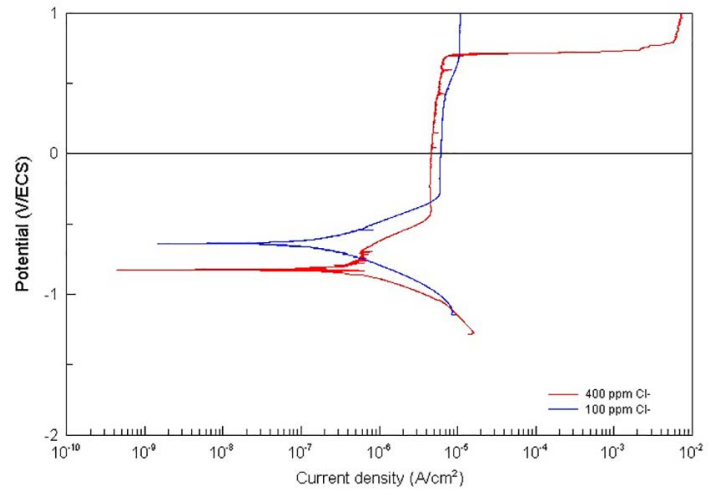

Figure 9. Potentiodynamic polarization curves for AA7075-T73 alloy in low (100 ppm) and high (400 ppm) chloride concentration machining fluid

The conditions leading to the lowest level of corrosion according to DOE (Figures 6 and 7), which are the zinccoated bench vice jaw and chloride concentration below $100 \mathrm{ppm}$ were applied in the multinational manufacturer company that supplied the AA7075-T73 alloy parts for the study. The scrap due to corrosion process in the machining step was reduced by over $95 \%$.

\section{Conclusions}

The corrosion of AA7075-T73 parts during machining process in aeronautical industry was studied. For this purpose, an experimental device was developed.

The effects of some process parameters were evaluated using a design of experiments.

The presence or not of a $\mathrm{Zn}$ coating on the bench vice jaw (part that holds the aluminum part during machining) and the chloride concentration in the machining fluid were the significant factors that affected the appearance of corrosion on aluminum parts.

There was also an interaction between the chloride concentration and the bench vice jaw state. High chloride concentration and a not coated bench vice jaw led to a higher corroded area.

Other investigated factors, such as waiting time to apply the protective oil, the machined part condition before the oil application and the iron contamination of the machining fluid were not significant for the occurence of corrosion on the AA7075-T73 parts.

These results may lead to significant changes in machining procedures for aeronautical components manufacture, like:

- There is no need to clean and dry the component part to apply the protective oil, reducing time during AA7075-T73 parts manufacture;

- Iron contamination of the machining fluid has no effect on corrosion of AA7075-T73 alloy;
- The waiting time to use the protective oil on the parts is acceptable up to 21 days. This leads to a great cost reduction due to decrease in oil consumption.

Electrochemical tests performed in machining fluid with low and high chloride concentrations (100 and 400 ppm) showed a passive behavior of AA7075-T73 in both solutions. Nevertheless, the alloy shows higher corrosion current density and passivation breakdown in high chloride concentration fluid.

\section{Acknowledgements}

The authors acknowledge financial support provided by CNPq (The Brazilian Research Council). The study is part of the RHAE PESQUISADOR NA EMPRESA project, process MCT/SETEC/CNPq n ${ }^{\circ} 32 / 2007$.

\section{References}

1. Faria MIST, Robin A, Prisco LP, Puccini MC, Gonçalves DC, Lourenço JC. Corrosion of Al 7075 alloy during the production of aeronautic components: Influence of process parameters at the deburring stage. Materials and Corrosion-Werkstoffe und Korrosion. 2013;64(12):1114-1120.

2. Lourenço JC, Faria MIST, Robin A, Prisco LP, Puccini MC. Influence of process parameters on localized corrosion of AA7075 alloy during the production of aeronautic components. Materials and Corrosion-Werkstoffe und Korrosion. 2015;66(12):14981503.

3. Polmear IJ. Light Alloys: From Traditional Alloys to Nanocrystals. $4^{\text {th }}$ ed. Oxford: Butterworth-Heinemann; 2005. 416 p.

4. Meng QJ, Frankel GS. Effect of $\mathrm{Cu}$ Content on Corrosion Behavior of 7xxx Series Aluminum Alloys. Journal of the Electrochemical Society. 2004;151(5):B271-B283.

5. Korb LJ, Olson DL, eds. Metals Handbook: Corrosion. $4^{\text {th }}$ ed. Materials Park: ASM International; 1992.

6. Park JK, Ardell AJ. Microstructures of the commercial-7075 Al-alloy in the T651-temper and T7-tempers. Metallurgical Transactions A. 1983;14(10):1957-1965.

7. Andreatta F, Lohrengel MM, Terryn H, de Wit JHW. Electrochemical characterisation of aluminium AA7075-T6 and solution heat treated AA7075 using a micro-capillary cell. Electrochimica Acta. 2003;48(20-22):3239-3247.

8. Singh SS, Schwartzstein C, Williams JJ, Xiao XH, De Carlo F, Chawla N. 3D microstructural characterization and mechanical properties of constituent particles in Al 7075 alloys using X-ray synchrotron tomography and nanoindentation. Journal of Alloys and Compounds. 2014;602:163-174.

9. Gupta VK, Agnew SR. Fatigue crack surface crystallography near crack initiating particle clusters in precipitation hardened legacy and modern Al-Zn-Mg-Cu alloys. International Journal of Fatigue. 2011;33(9):1159-1174.

10. Wei RP, Liao CM, Gao M. A transmission electron microscopy study of constituent-particle-induced corrosion in 7075-T6 
and 2024-T3 aluminum alloys. Metallurgical and Materials Transactions A. 1998;29(4):1153-1160.

11. Tian WM, Li SM, Chen X, Liu JH, Yu M. Intergranular corrosion of spark plasma sintering assembled bimodal grain sized AA7075 aluminum alloys. Corrosion Science. 2016;107:211-224.

12. Pang JJ, Liu FC, Liu J, Tan MJ, Blackwood DJ. Friction stir processing of aluminium alloy AA7075: Microstructure, surface chemistry and corrosion resistance. Corrosion Science. 2016;106:217-228.

13. Reboul MC, Baroux B. Metallurgical aspects of corrosion resistance of aluminium alloys. Materials and CorrosionWerkstoffe und Korrosion. 2011;62(3):215-233.

14. Abreu CM, Cristóbal MJ, Figueroa R, Pena G. Wear and corrosion performance of two different tempers (T6 and T73) of AA7075 aluminium alloy after nitrogen implantation. Applied Surface Science. 2015;327:51-61.

15. Baker H, Okamoto H, Henry SD, Davidson GM, Fleming MA, Kacprzak L, et al., eds. ASM Handbook Volume 3: Alloy Phase Diagrams. $1^{\text {st }}$ ed. Materials Park: ASM International; 1992. $1741 \mathrm{p}$.
16. Vargel C. Corrosion of Aluminium. $1^{\text {st }}$ ed. Paris: Elsevier; 2004. $601 \mathrm{p}$.

17. Andreatta F, Terryn H, de Wit JHW. Corrosion behaviour of different tempers of AA7075 aluminium alloy. Electrochimica Acta. 2004;49(17-18):2851-2862.

18. Kostadin T, Cukor G, Jurkovic Z. Influence of Cutting Fluids on the Corrosion Resistance of X20Cr13 Martensitic Stainless Steel. International Journal of Electrochemical Science. 2018;13:11986-11999.

19. Ramakrishnan V, Rajagopal C, Subramanian V. Corrosion of copper in cutting fluids. Bulletin of Electrochemistry. 1985;1(6):543-547.

20. Trim Technical Bulletin. Metal Removal Fluids and Corrosion - Frequent Sources of the Problem. Perrysburg: Trim; 2006.

21. Zhu J, Yan P, Jiao L, Peng Z, Wang P, Wang X, et al. Effect of cutting fluids on corrosion properties and turning surface quality of Fe-based superally. Advances in Mechanical Engineering. 2017;9(11). DOI: 10.1177/1687814017730534:1-9. 